\title{
INDUCING DROUGHT TOLERANCE IN WHEAT THROUGH COMBINED USE OF L-TRYPTOPHAN AND Pseudomonas fluorescens
}

\author{
Moazzam Jamil', Maqshoof Ahamd ${ }^{1, *}$, Faisal Anwar', Zahir Ahmad Zahir ${ }^{2}$, Muhammad Ali \\ Kharal $^{1}$ and Farheen Nazli ${ }^{3}$ \\ ${ }^{1}$ Department of Soil Science, University College of Agriculture and Environmental Sciences, The Islamia University \\ of Bahawalpur, Pakistan; ${ }^{2}$ Institute of Soil and Environmental Sciences, University of Agriculture, Faisalabad, \\ Pakistan; ${ }^{3}$ Pesticide Quality Control Laboratory, Bahawalpur, Pakistan. \\ "Corresponding Author's e-mail: maqshoof_ahmad@yahoo.com
}

\begin{abstract}
Auxins, as phytohormones and osmo-protectant, play important role to alleviate the adverse effect of drought stress on plant growth. Some bacteria equipped with ACC-deaminase activity along with some other growth promoting traits are helpful in improving plant growth under stresses. The efficiency of these bacteria is further improved when inoculation is supplemented with exogenous plant growth regulators. The combined use of these bacteria with auxins may be more effective under stressed conditions. A pot experiment was conducted to evaluate the efficacy of Pseudomonas fluorescens containing ACC-deaminase in combination with L-tryptophan for reducing drought stress in wheat. The P. fluorescens and L-tryptophan (@ 25 ppm) were applied, solely and in combination, on wheat by inducing drought stress at different growth stages. The foliar application of Ltryptophan was started after 15 days of germination and was repeated every week up to 2 weeks after grain filling stage. The results showed significant reduction in all parameters under drought. However, combined application of L-tryptophan @ 25 ppm and P. fluorescens significantly improved plant height (45.65\%), root length (81\%), chlorophyll-a (94\%), chlorophyll-b (72\%), carotenoid contents $(98 \%)$, relative water contents $(33 \%), \mathrm{Na}^{+} / \mathrm{K}^{+}$ratio in leaves $(49 \%)$ and grains $(43 \%)$, spike length (64\%) and 1000 grains weight (75\%) under drought stress. Consequently, it may be concluded that combined use of Ltryptophan @ $25 \mathrm{ppm}$ and $P$. fluorescens is an effective approach to improve wheat productivity under water limited conditions but it should be evaluated extensively under field studies before its recommendation to the farmers.
\end{abstract}

Keywords: ACC-deaminase, Drought, L-tryptophan, Pseudomonas fluorescens, Wheat

\section{INTRODUCTION}

Wheat is the world most cultivated crop, consumed as staple food for about one third of world's population (Charkazi et al., 2010). It is considered as one of the most copious source of energy and sustenance for about 7.3 billion humans on this planet (Debasis and Paramjit, 2003). However, due to global climatic change, scarcity of water is becoming a key challenge for its production worldwide (Foley et al., 2011; Flexas et al., 2013). Drought is a polygenic stress and is considered as one of the most important factors limiting wheat production around the world. It adversely affects growth and yield of wheat (Arshad et al., 2008). The deleterious effects of water shortage on crop yield may be more obvious at some particular growth stage depending upon the nature of crop and species (Arshad et al., 2008). So, to nourish rapidly increasing population, it is the topic of immense importance that we should improve our understanding in improving plant survival under drought conditions (Timmusk et al., 2014).

Several techniques have been used to improve plant capability to cope with drought stress. The most emphasized technique by the researchers is the development of drought tolerance in plants through breeding and genetic engineering (Fleury et al., 2010). On the other hand, drought stress tolerance is a multifaceted characteristic and a large number of genes are tangled in controlling this attribute (Price et al., 2002; Wang et al., 2003; Fleury et al., 2010). Therefore, a gigantic gap persists in addressing the issue due to the severe limitations in conventional and modern breeding techniques for the development of drought tolerant characters in plants (Niinemets, 2010; Timmusk et al., 2014). To ensure food security to feed rapidly growing population, relatively simple and low cost techniques were also developed by the scientists, i.e. the use of biofertilizers containing plant growth promoting bacteria (PGPB) and the use of different polyamines and osmolytes as stress protectants (Javaid et al., 2011; Timmusk and Behers, 2012).

The soil surrounding roots is the concentrated region of microbial activity. These microbes include several types of plant growth promoting bacteria that help plants to withstand stress conditions (Timmusk and Wagner, 1999; Nadeem et al., 2014). These PGPB help plants to survive under water deficit conditions through induced systemic resistance by bacterially produced compounds and formation of extracellular matrix (biofilms) in root zone (Timmusk and Nevo, 2011; Nadeem et al., 2014). 
In many plants, natural accumulation of osmolytes is insufficient to ameliorate the adverse effects of environmental stresses (Subbarao et al., 2001). Exogenous application of osmolytes to drought sensitive plants may help to reduce adverse effects of drought (Yang and Lu, 2005). Exogenous applications of osmolytes to plants under drought stress results in increased endogenous level of osmolytes in plants, helping them to tolerate stress (Ashraf and Foolad, 2007). Bacterially produced compounds, including different phytohormones, essential enzymes, and formation of extracellular matrix in root zone, play an important role in improving moisture availability to plants (Chang et al., 2007). Enhancing endogenous level of different osmolytes in plant through exogenous application is a proven strategy for inducing stress tolerance in plants (Ashraf and Foolad, 2007). Auxins are among the most important phytohormones that regulate plant osmotic relations under drought conditions (Rao et al., 2012). They also help plants to mediate detoxification of different toxic ions and free radicals produced due to the disturbance in plant internal osmotic potential under drought stress (Rai, 2002). Keeping in view the importance of PGPB and auxins to improve plant drought stress tolerance, as a low cost and rapid strategy, present study was conducted to evaluate the comparative effect of exogenous application of auxins and Pseudomonas fluorescens on wheat crop under drought conditions at different developmental stages.

\section{MATERIALS AND METHODS}

Plant material: Promising wheat cultivar AAS-2011 (Punjab Seed Corporation) was selected for sowing in pot trial.

Pot experiment: A pot experiment was conducted to evaluate the potential of exogenously applied L-tryptophan and $P$. fluorescens to alleviate the effect of drought stress on wheat. The experiment was conducted with a set of treatments as: No application i.e. control; L-tryptophan @ $25 \mathrm{ppm} ; \quad P$. fluorescens; L-tryptophan @ 25 ppm and P. fluorescens with three levels of drought i.e. D0; normal irrigation with 10 days interval (control), D1; skipped one irrigation at booting stage and D2; skipped irrigation at grain filling stage. The irrigation was applied with 10 days interval but in the treatments with drought, the interval was extended to 20 days at the stage of drought induction. Each polythene lined pot was filled with $12 \mathrm{~kg}$ of soil.

The general purpose media without agar (broth) was used for inoculum. Flask containing broth was inoculated with Pseudomonas strain and incubated at $28 \pm 1{ }^{\circ} \mathrm{C}$ for 72 hours under shaking $(100 \mathrm{rpm})$. Before inoculation, the optical density (OD) of broth culture was measured and brought to $\mathrm{OD}_{540}=0.45 ; 10^{7}-10^{8} \mathrm{cfu} \mathrm{mL}^{-1}$ using distilled water. The seeds were inoculated by soaking them in inoculum for 10 minutes while L-tryptophan @ 25 ppm was applied through foliar application. The plants were sprayed with L-tryptophan until their leaves become wet. The application of Ltryptophan was started after 15 days of germination and was repeated with every week interval up to 2 weeks after grain filling stage.

Recommended dose of NPK fertilizers (120: 110: $60 \mathrm{~kg} \mathrm{ha}^{-1}$ ) was applied in each pot as urea, diammonium phosphate and sulphate of potash, respectively. Full dose of $\mathrm{P}$ and $\mathrm{K}$, and $1 / 4^{\text {th }}$ of nitrogen was applied as basal dose at the time of sowing. The remaining $\mathrm{N}$ was applied in three splits with intervals of 15 days. Pots were irrigated with good quality irrigation water meeting the irrigation quality criteria for crop. After germination, thinning was done to maintain the uniform plant population.

Plant analysis: For plant analysis, leaves were sampled after 7 days from last application of L-tryptophan. While, grain samples were collected at harvest of crop. Leaf and grain samples were digested by using $\mathrm{H}_{2} \mathrm{SO}_{4}$ and $\mathrm{H}_{2} \mathrm{O}_{2}$ as described by Wolf (1982). The $\mathrm{Na}^{+}$and $\mathrm{K}^{+}$were determined on flame photometer as described by Ryan et al. (2001). Relative water contents were determined by the method of Barrs and Weatherley (1962).

Statistical analysis: Analysis of variance techniques (ANOVA) were applied to evaluate the data (Steel et al., 1997) using CRD factorial with three replications and means were compared by using LSD at 5\% level of significance.

\section{RESULTS}

Effect on growth attributes: The results (Table 1 and 2) showed that drought stress during different growth stages of wheat significantly reduced plant growth attributes including plant height $(33.26 \%$ at D1 and $7 \%$ at D2), root length (35.64\% at D1 and 6\% at D2) and root dry weight (52.78\% at D1 and $25 \%$ at D2) with maximum decrease when drought was induced at booting stage. However, the exogenous application of L-tryptophan (@25 ppm) and P. fluorescens, individually and in combination, significantly enhanced plant growth and alleviated the adverse effect of drought on wheat growth. The maximum increase in plant height $(18.46 \%$ at D0, $45.65 \%$ at D1 and 22.65), root length (63\% at D0, 81.2\% at D1 and $40.57 \%$ at D2) and root dry weight (50\% at D0, $111 \%$ at D1 and $63 \%$ at D2) was observed when L-tryptophan (@ $25 \mathrm{ppm}$ ) and $P$. fluorescens were applied in combination under all drought levels.

Effect on yield attributes: The results (Table 3) regarding yield attributes i.e. spike length and 1000 grain weight, revealed that maximum decrease in spike length $(46 \%)$ and 1000 grain weight $(31.11 \%)$ was observed at D1 and D2, respectively. However, application of L-tryptophan (@ 25 ppm) and P. fluorescens, alone and in combination, resulted in significant increase in yield of wheat under normal as well as drought conditions. Results also revealed that combined application of L-tryptophan @ 25 ppm and P. fluorescens resulted in maximum enhancement in yield. 
Table 1. Effect of L-tryptophan and Pseudomonas fluorescens on plant height and relative water contents under drought stress in wheat $(n=3)$.

\begin{tabular}{|c|c|c|c|}
\hline Treatment & Normal irrigation & Drought at booting & Drought at grain filling \\
\hline & \multicolumn{3}{|c|}{ Plant height $(\mathbf{c m})$} \\
\hline Control & $71.33 \pm 5.86 \mathrm{de}$ & $47.60 \pm 3.27 \mathrm{i}$ & $66.33 \pm 5.17 \mathrm{fg}$ \\
\hline L-tryptophan@25 ppm & $77.40 \pm 1.27 \mathrm{bc}$ & $63.67 \pm 3.39 \mathrm{~g}$ & $74.30 \pm 3.343 \mathrm{~cd}$ \\
\hline P. fluorescens & $76.30 \pm 4.79 c$ & $57.67 \pm 2.77 \mathrm{~h}$ & $76.67 \pm 3.57 \mathrm{c}$ \\
\hline L-Tryp.@25 ppm + P.fluorescens & $84.50 \pm 5.64 \mathrm{a}$ & $69.33 \pm 3.56$ ef & $81.35 \pm 2.20 \mathrm{ab}$ \\
\hline $\operatorname{LSD}(p \leq 0.05)$ & \multirow{2}{*}{\multicolumn{3}{|c|}{$\begin{array}{l}3.9702 \\
\text { Relative water contents }(\%)\end{array}$}} \\
\hline & & & \\
\hline Control & $72.49 \pm 1.39 \mathrm{de}$ & $62.14 \pm 2.57 \mathrm{fg}$ & $55.48 \pm 3.51 \mathrm{~g}$ \\
\hline L-tryptophan@25 ppm & $79.80 \pm 0.54 \mathrm{bc}$ & $75.72 \pm 1.69 \mathrm{~b}-\mathrm{d}$ & $67.39 \pm 2.48$ ef \\
\hline P. fluorescens & $80.52 \pm 2.29 \mathrm{bc}$ & $75.33 \pm 1.66 \mathrm{~cd}$ & $65.27 \pm 2.68 \mathrm{f}$ \\
\hline $\begin{array}{l}\text { L-Tryp.@ } @ 25 \mathrm{ppm}+P . \text { fluorescens } \\
\text { LSD }(\mathrm{p} \leq 0.05)\end{array}$ & $87.69 \pm 1.17 \mathrm{a}$ & $\begin{array}{c}82.29 \pm 2.75 \mathrm{ab} \\
\mathbf{6 . 8 6 6 5}\end{array}$ & $72.54 \pm 5.69 \mathrm{de}$ \\
\hline
\end{tabular}

Means sharing different letters are statistically significant from each other at 5\% probability level

Table 2. Effect of L-tryptophan and Pseudomonas fluorescens on root length and root dry weight under drought stress $(n=3)$.

\begin{tabular}{|c|c|c|c|}
\hline Treatment & Normal irrigation & Drought at booting & Drought at grain filling \\
\hline \multicolumn{4}{|c|}{ Root length $(\mathbf{c m})$} \\
\hline Control & $9.37 \pm 1.17 \mathrm{de}$ & $6.03 \pm 2.34 \mathrm{f}$ & $8.80 \pm 1.58 \mathrm{e}$ \\
\hline L-tryptophan@25 ppm & $11.53 \pm 1.24 \mathrm{bc}$ & $8.07 \pm 2.32 \mathrm{e}$ & $10.57 \pm 0.38 \mathrm{~cd}$ \\
\hline P. fluorescens & $11.93 \pm 1.15 \mathrm{bc}$ & $8.63 \pm 2.89 \mathrm{e}$ & $11.00 \pm 1.16 \mathrm{bc}$ \\
\hline L-Tryp.@25 ppm + P.fluorescens & $15.27 \pm 2.08 \mathrm{a}$ & $10.93 \pm 2.11 \mathrm{bc}$ & $12.30 \pm 0.43 b$ \\
\hline $\operatorname{LSD}(p \leq 0.05)$ & \multirow{2}{*}{\multicolumn{3}{|c|}{$\begin{array}{c}1.5554 \\
\text { Root dry weight }\left(\mathrm{g} \mathrm{plant}^{-1}\right)\end{array}$}} \\
\hline & & & \\
\hline Control & $0.36 \pm 0.03 \mathrm{c}$ & $0.17 \pm 0.03 \mathrm{e}$ & $0.27 \pm 0.05 \mathrm{~d}$ \\
\hline L-tryptophan@25 ppm & $0.49 \pm 0.05 \mathrm{ab}$ & $0.22 \pm 0.02 \mathrm{de}$ & $0.34 \pm 0.06 \mathrm{c}$ \\
\hline P. fluorescens & $0.44 \pm 0.05 \mathrm{~b}$ & $0.24 \pm 0.01 \mathrm{~d}$ & $0.36 \pm 0.05 \mathrm{c}$ \\
\hline L-Tryp.@25 ppm + P.fluorescens & $0.54 \pm 0.05 \mathrm{a}$ & $0.36 \pm 0.02 \mathrm{c}$ & $0.44 \pm 0.06 b$ \\
\hline $\operatorname{LSD}(p \leq 0.05)$ & & 0.0658 & \\
\hline
\end{tabular}

Means sharing different letters are statistically significant from each other at $5 \%$ probability level

Table 3. Effect of L-tryptophan and Pseudomonas fluorescens on spike length and 1000 grain weight under drought stress $(\mathbf{n}=3)$.

\begin{tabular}{lccc}
\hline Treatment & Normal irrigation & Drought at booting & Drought at grain filling \\
\hline & & Spike length $(\mathbf{c m})$ & \\
Control & $12.57 \pm 1.62 \mathrm{dc}$ & $6.77 \pm 2.27 \mathrm{~g}$ & $10.6 \pm 1.49 \mathrm{ef}$ \\
L-tryptophan @ 25 ppm & $14.23 \pm 2.23 \mathrm{bc}$ & $8.93 \pm 2.48 \mathrm{e}-\mathrm{g}$ & $12.23 \pm 0.66 \mathrm{de}$ \\
P.fluorescens & $14.77 \pm 1.58 \mathrm{~b}$ & $8.97 \pm 2.31 \mathrm{fg}$ & $12.10 \pm 1.27 \mathrm{de}$ \\
L-Tryp. @ 25 ppm + P. fluorescens & $17.27 \pm 2.46 \mathrm{a}$ & $11.13 \pm 2.36 \mathrm{de}$ & $15.17 \pm 1.40 \mathrm{~b}$ \\
LSD(p $\leq 0.05)$ & & $\mathbf{1 . 8 6 4 7}$ \\
& & $\mathbf{1 0 0 0}$ grain weight $(\mathbf{g})$ & \\
Control & $4.50 \pm 0.36 \mathrm{c}-\mathrm{e}$ & $4.00 \pm 0.58 \mathrm{ef}$ & $3.1 \pm 0.39 \mathrm{f}$ \\
L-tryptophan @ 25 ppm & $5.53 \pm 0.30 \mathrm{a}-\mathrm{c}$ & $4.5 \pm 0.17 \mathrm{c}-\mathrm{e}$ & $4.13 \pm 0.31 \mathrm{~d}-\mathrm{f}$ \\
$P$. fluorescens & $5.50 \pm 0.33 \mathrm{~b}-\mathrm{d}$ & $4.6 \pm 0.24 \mathrm{c}-\mathrm{e}$ & $4.33 \pm 0.47 \mathrm{c}-\mathrm{f}$ \\
L-Tryp. @ 25 ppm + P. fluorescens & $6.80 \pm 0.25 \mathrm{a}$ & $5.97 \pm 0.29 \mathrm{ab}$ & $5.43 \pm 13 \mathrm{~b}-\mathrm{d}$ \\
LSD (p $\leq 0.05)$ & & $\mathbf{1 . 3 0 9 8}$ & \\
\hline
\end{tabular}

Means sharing different letters are statistically significant from each other at 5\% probability level

Effect on physiological attributes: The results showed that under drought stress ionic balance of leaves also significantly disrupted as $\mathrm{Na}^{+} \backslash \mathrm{K}^{+}$ratio in leaves and grains (Table 4) was significantly increased under water deficit conditions. However, $\mathrm{Na}^{+} \backslash \mathrm{K}^{+}$ratio in leaves and grains significantly decreased in all cases (normal and drought) when Ltryptophan (@25 ppm) and P. fluorescens were applied solely and in combination, while the combined application of both resulted in maximum decrease in $\mathrm{Na}^{+} \backslash \mathrm{K}^{+}$ratio in leaves and grains than of sole application. Similarly, in the case of 
Table 4. Effect of L-tryptophan and Pseudomonas fluorescens on $\mathrm{Na}^{+} \backslash \mathrm{K}^{+}$ratio in leaves and $\mathrm{Na}^{+} \backslash \mathrm{K}^{+}$ratio in grains under drought stress $(n=3)$.

\begin{tabular}{|c|c|c|c|}
\hline Treatment & Normal irrigation & Drought at booting & Drought at grain filling \\
\hline & & $\mathrm{Na}^{+} \backslash \mathrm{K}^{+}$ratio in leaves & \\
\hline Control & $0.527 \pm 0.012 \mathrm{e}$ & $0.743 \pm 0.021 \mathrm{c}$ & $1.010 \pm 0.042 \mathrm{a}$ \\
\hline L-tryptophan@25 ppm & $0.367 \pm 0.007 \mathrm{f}$ & $0.537 \pm 0.002 \mathrm{e}$ & $0.834 \pm 0.010 \mathrm{~b}$ \\
\hline P. fluorescens & $0.347 \pm 0.007 \mathrm{f}$ & $0.533 \pm 0.012 \mathrm{e}$ & $0.833 \pm 0.003 \mathrm{~b}$ \\
\hline L-Tryp.@ 25 ppm + P. fluorescens & $0.270 \pm 0.013 \mathrm{~g}$ & $0.377 \pm 0.015 \mathrm{f}$ & $0.640 \pm 0.015 \mathrm{~d}$ \\
\hline $\operatorname{LSD}(p \leq 0.05)$ & & $\begin{array}{l}0.0558 \\
\end{array}$ & \\
\hline & & $\mathrm{Na}^{+} \backslash \mathrm{K}^{+}$ratio in grains & \\
\hline Control & $1.010 \pm 0.042 \mathrm{a}$ & $0.457 \pm 0.014 \mathrm{~d}$ & $0.623 \pm 0.014 \mathrm{c}$ \\
\hline L-tryptophan@25 ppm & $0.834 \pm 0.010 \mathrm{~b}$ & $0.340 \pm 0.005 \mathrm{e}$ & $0.510 \pm 0.019 \mathrm{~d}$ \\
\hline P. fluorescens & $0.833 \pm 0.003 b$ & $0.343 \pm 0.010 \mathrm{e}$ & $0.470 \pm 0.017 \mathrm{~d}$ \\
\hline $\begin{array}{l}\text { L-Tryp.@25 ppm + P. fluorescens } \\
\text { LSD }(\mathfrak{p}<0.05)\end{array}$ & $0.640 \pm 0.015 \mathrm{~d}$ & $\begin{array}{c}0.263 \pm 0.014 \mathrm{f} \\
\mathbf{0 . 0 5 9 0}\end{array}$ & $0.357 \pm 0.014 \mathrm{e}$ \\
\hline
\end{tabular}

Means sharing different letters are statistically significant from each other at 5\% probability level.

relative water contents (RWC) in leaves (Table 1), significant reduction in RWC resulted under drought stress while the application of L-tryptophan (@25 ppm) and P. fluorescens, individually as well as together, significantly increased RWC in leaves with maximum increase when L-tryptophan (@ 25 ppm) and P. fluorescens were applied in combination.

Under drought stress photosynthetic ability of wheat significantly reduced as results showed that significant reduction in chlorophyll-a (Fig. 1), chlorophyll-b (Fig. 2) and carotenoid contents (Fig. 3) was observed (up to $41.5 \%$, $43.5 \%$ and $67 \%$, respectively) due to disintegration of these pigments caused by osmotic stress. The results (Fig. 1, 2 \& 3) showed that maximum decrease in all photosynthetic pigments was observed under drought stress at grain filling stage. The application of L-tryptophan (@25 ppm) and $P$. fluorescens ameliorated the adverse effect of drought stress on photosynthetic pigments, resulting in significant increase in chlorophyll-a (up to $93.8 \%$ ), chlorophyll-b (up to $71.6 \%$ ) and carotenoid contents (up to 98.2\%) under drought as well as normal conditions.

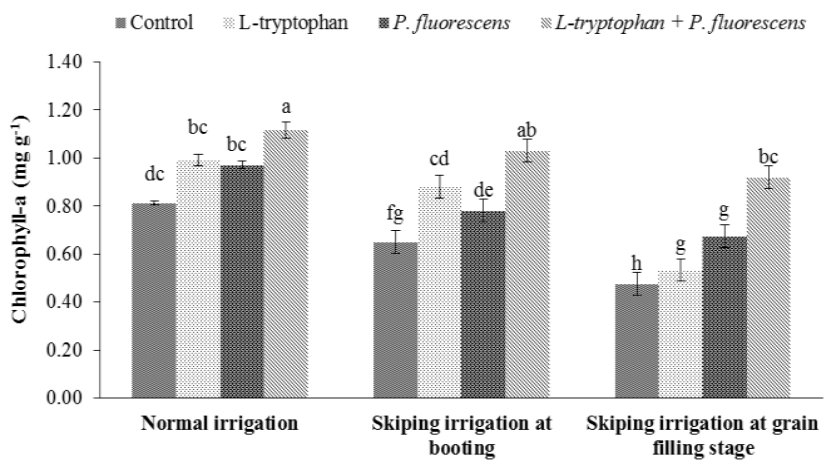

Figure 1. Effect of L-tryptophan and Pseudomonas fluorescens on chlorophyll-a content of wheat under drought stress (LSD $\mathbf{p} \leq \mathbf{0 . 0 5}=\mathbf{0 . 1 4 5 5}$; $\mathbf{n = 3}$ ). Bars sharing different letters are statistically significant from each other at 5\% probability level.

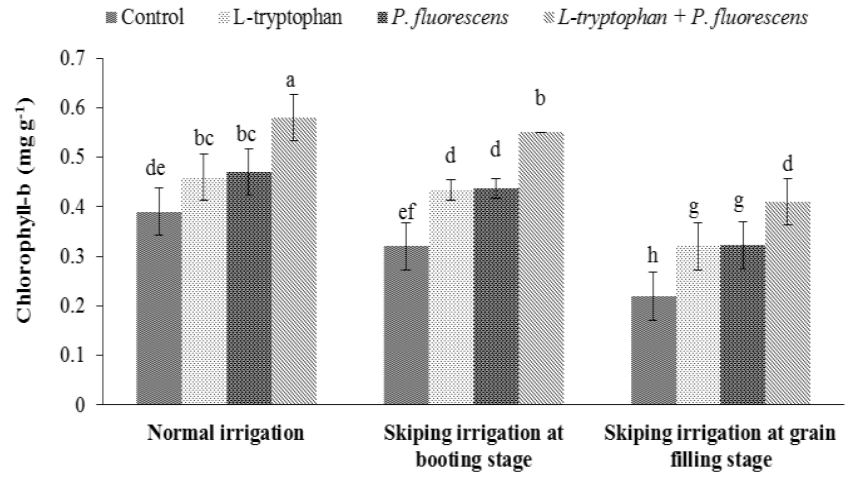

Figure 2. Effect of L-tryptophan and Pseudomonas fluorescens on chlorophyll-b content of wheat under drought stress (LSD $\mathrm{p} \leq \mathbf{0 . 0 5}=\mathbf{0 . 1 4 5 5}$; $\mathbf{n = 3}$ ). Bars sharing different letters are statistically significant from each other at 5\% probability level.

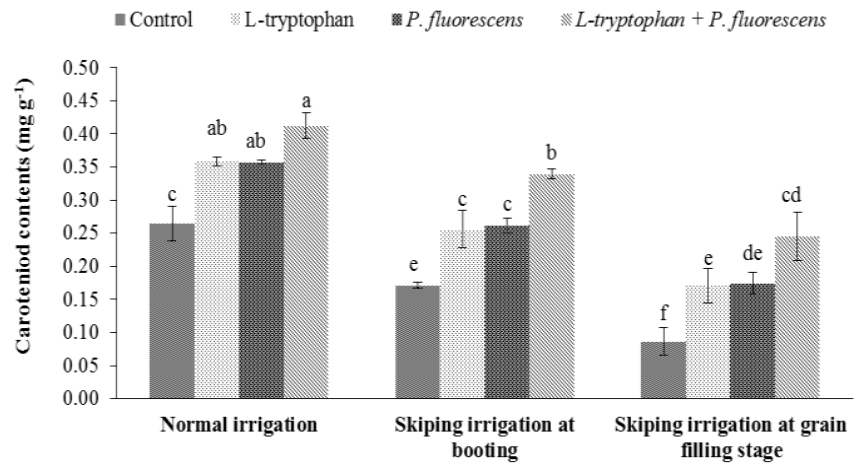

Figure 3. Effect of L-tryptophan and Pseudomonas fluorescens on carotenoid content of wheat under drought stress (LSD $p \leq 0.05=0.0719 ; n$ $=3$ ). Bars sharing different letters are statistically significant from each other at $5 \%$ probability level. 


\section{DISCUSSION}

The findings of our study showed that wheat growth and yield was adversely effected by drought stress. This reduction might be attributed to the inhibition of cell expansion due to inhibited activity of enzymes and disturbance in accumulation of essential solutes under low availability of water (Csiszar et al., 2007; Suzuki et al., 2008; Hessini et al., 2009). Due to reduction in cell growth and expansion, root, shoot and spike development is severely reduced and plants remain stunted (Bhatt and Rao, 2005). Drought at booting stage results in the early shifting towards reproductive phase, which cause fewer spikelets per spike and reduced spike length (Saini and Westgate, 2000). Ji et al. (2011) also reported that drought stress reduced grain yield due to disturbance in auxins and absicisic acid equilibrium that decreased spike growth (Cattivelli et al., 2008). Induction of drought stress during grain filling enhances the rate of grain filling that results in lower assimilation of proteins and starch resulting in small and lighter grains leading to reduced grain yield (Yang et al., 2004).

The study revealed that L-tryptophan and $P$. fluorescens resulted in significant improvement in plant growth and yield. Similarly, Jaleel et al. (2007) reported that the application of biofertilizer (containing $P$. fluorescens) improved the growth and yield under drought stress. Application of Pseudomonas fluorescens enhance plant growth through many mechanisms including production of siderophores and antibiotics, providing phytohormones (auxins, gibberellins, etc.), augmentation of nutrients uptake by the plant, nitrogen fixation and production of enzymes (ACC deaminase) that controls ethylene levels. It also improves soil physical conditions that increase the water holding capacity of soil which decrease stress intensity, resulting in better growth and development (Heulin et al., 1987; Alami et al., 2000). Abdoli et al. (2013) reported that the exogenous application of auxins resulted in significant improvement in growth and yield of wheat plant. The L-tryptophan is primary precursor for auxins production in plants as well as bacteria. Auxins are considered as natural regulator of plant growth that controls the development of young tissues and cell division (Zahir et al., 1999; Wang et al., 2008). Under drought stress, auxins regulate the vacuolar osmotic pressure and mediate the translocation of different metabolites required for cell elongation, thus improve osmotic balance and growth under water deficit conditions (Awan et al., 1999). In our studies, the application of L-tryptophan significantly improved the physiological parameters in wheat. Similarly, Hussain et al. (2008) reported that application of exogenous auxins significantly improved growth and photosynthetic activity in crop plants under stress. The improvement in physiology is attributed to the enhanced ROS scavenging ability of plant due to regulation of hormones. Higher level of auxins also mediates plant water relations and vacuolar turgor pressure.
Drought stress also disturbed ionic balance resulted in increased $\mathrm{Na}^{+} / \mathrm{K}^{+}$that also adversely affected leaf relative water contents (RWC) and deteriorated chlorophyll pigments due to membrane collapse caused by oxidative damage (Hafsi et al., 2000). Under drought stress, reduction in $\mathrm{K}$ uptake results in decreased osmotic regulation and elevated $\mathrm{Na}^{+} \mid \mathrm{K}^{+}$ ratio (Grossman and Takahashi, 2001). The results were also strengthened by the work of Asada (2006) under drought stress who reported oxidation of chloroplasts by the production of super oxide and other reactive oxygen species (ROS). Chloroplasts are oxidized by the production of super oxides and other reactive oxygen species (ROS) resulting in severe decrease in chlorophyll contents (Farooq et al., 2014). Results showed that application of L-tryptophan and $P$. fluorescens resulted in significant improvement in chlorophyll pigments. Our findings were in line with Rao et al. (2012). They concluded that the exogenous application of auxins under drought stress significantly amended the adverse effects and enhanced the chlorophyll-a, chlorophyll-b and carotenoids contents in leaves. Inoculation with $P$. fluorescens under drought resulted in increased photosynthetic activity due to the improved hormonal balance and reduced ethylene production, thus prevented the breakdown of chlorophyll proteins. Bacterial exudates in root zone stimulated the production of different osmo-protectants that resulted in improved water regulation. These also improve the ability of plant to regulate the uptake of toxic ions and managing $\mathrm{Na}^{+} \backslash \mathrm{K}^{+}$ratio (Shaharoona et al., 2008; Dodd et al., 2010; Saharan and Nera, 2011). These bacteria are supremely suitable as soil inoculants because of the ability for quick and aggressive establishment in the rhizosphere (Jaleel et al., 2007). The combined application of $P$. fluorescens and L-tryptophan significantly improved the growth, yield and physiology of wheat under drought conditions thus precursorinoculum interaction can be explored as a breakthrough for improving wheat productivity under water limited conditions.

Conclusion: Drought stress at different developmental stages significantly reduced the growth and yield of wheat crop. Exogenous application of L-tryptophan along inoculation with $P$. fluorescens improved growth, physiology and yield of wheat significantly, both under drought stress and normal conditions. Moreover, the combined application of Ltryptophan and $P$. fluorescens was more effective than their sole application. These findings need to be extensively assessed under field conditions before its recommendation to the farmers.

Acknowledgement: We are thankful to the Islamia University of Bahawalpur for providing the financial support and research facilities for this project. We also acknowledge the services of Saqib Imran Principal, Superior College Rahim Yar Khan Campus to edit this manuscript. 


\section{REFERENCES}

Abdoli, M., M. Saeidi, S.J. Honarmand and M. Azhand. 2013. The effect of foliar application of indole-3-acetic acid and roles of ear photosynthesis on grain yield production of two wheat cultivars (Triticum aestivum L.) under post anthesis water deficit. Int. Res. J. Appl. Basic Sci. 4:1406-1413.

Alami, Y., W. Achouak, C. Marol and T. Heulin. 2000. Rhizosphere soil aggregation and plant growth promotion of sunflowers by an exopolysaccharideproducin Rhizobium sp strain isolated from sunflower roots. Appl. Environ. Microbiol. 66:3393-3398.

Arshad, M., B. Shaharoona and T. Mahmood. 2008. Inoculation with Pseudomonas spp. containing ACCdeaminase partially eliminates the effects of drought stress on growth, yield, and ripening of pea (Pisum sativum L.). Pedosphere 18:611-620.

Asada, K. 2006. Production and scavenging of reactive oxygen species in chloroplasts and their functions. Plant Physiol. 141:391-396.

Ashraf, M. and M.R. Foolad. 2007. Roles of glycine betaine and proline in improving plant abiotic stress resistance. Environ. Exp. Bot. 59:206-216.

Awan, I.U., M.S. Baloch, N.S. Sadozai and M.Z. Sulemani. 1999. Stimulatory effect of GA3 and IAA on ripening process, kernel development and quality of rice. Pak. J. Biol. Sci. 2:410-412.

Barrs, H.D. and P.E. Weatherley. 1962. A re-examination of the relative turgidity technique for estimating water deficits in leaves. Aust. J. Biol. Sci. 15:413-428.

Bhatt, R.M. and N.K.S. Rao. 2005. Influence of pod load on response of okra to water stress. Ind. J. Plant Physiol. 10:54-59.

Cattivelli, L., F. Rizza, F.W. Badeckc, E. Mazzucotelli, A.M. Mastrangelo, E. Franciaa, C. Marea, A. Tondellia and A.M. Stanca. 2008. Drought tolerance improvement in crop plants an integrated view from breeding to genomics. Field Crops Res. 105:1-14.

Chang, W.S., M. Vande-Mortel, L. Nielsen, G. NinodeGuzman and X. Li. 2007. Alginate production by Pseudomonas putida creates a hydrated microenvironment and contributes to biofilm architecture and stress tolerance under water limiting conditions. J. Bacteriol. 189:8290-8299.

Charkazi, F., S.S. Ramezanpour and H. Soltanloo. 2010. Expression pattern of two sugar transporter genes (SuT4 and SuT5) under salt stress in wheat. Aust. J. Crop Sci. 3:194-198.

Csiszar, J., E. Lantos, I. Tari, E. Madosa, B. Wodala, A. Vashegyi, F. Horvath, A. Pecsvaradi, M. Szabó, B. Bartha, A. Galle, A. Lazar, G. Coradini, M. Staicu, S. Postelnicu, S. Mihacea, G. Nedelea and L. Erdei. 2007. Antioxidant enzyme activities in Allium species and their cultivars under water stress. Plant Soil Environ. 53:517523.

Debasis, P. and K.H. Paramjit. 2003. Genetic transformation of Indian bread (T. aestivum) and pasta (T. durum) wheat by particle bombardment of mature embryo-derived calli. Biol. Med. Central Plant Biol. 3:3-5.

Dodd, I.C., N.Y. Zinovkina, V.I. Safronova and A.A. Belimov. 2010. Rhizobacterial mediation of plant hormone status. Ann. Appl. Biol. 157:361-379.

Farooq, M., M.K. Hussain and H.M. Siddique. 2014. Drought stress in wheat during flowering and grain-filling periods. Crit. Rev. Plant Sci. 33:331-349.

Fleury, D., S. Jefferies, H. Kuchel and P. Langridge. 2010. Genetic and genomic tools to improve drought tolerance in wheat. J. Exp. Bot. 61:3211-3222.

Flexas, J., U. Niinemets, A. Galle, M.M. Barbour and M. Centritto. 2013. Diffusional conductances to $\mathrm{CO}_{2}$ as a target for increasing photosynthesis and photosynthetic water-use efficiency. Photosynthesis Res. 117:1-3.

Foley, J.A., N. Ramankutty, K.A. Brauman, E.S. Cassidy and J.S. Gerber. 2011. Solutions for a cultivated planet. Nature 478:337-342.

Grossman, A. and H. Takahashi. 2001. Macronutrient utilization by photosynthetic eukaryotes and the fabric of interactions. Ann. Rev. Plant Physiol. 52:163-210.

Hafsi, M., W. Mechmeche, L. Bouamama, A. Djekoune, M. Zaharieva and P. Monneveux. 2000. Flag leaf senescence as evaluated by numerical image analysis and its relationship with yield under drought in durum wheat. J. Agron. Crop Sci. 185:275-280.

Hessini, K., M. Lacha, C. Cruz and A. Soltani. 2009. Role of ammonium to limit nitrate accumulation and to increase water economy in wild Swiss chard. J. Plant Nut. 32:821836.

Heulin, T., A. Gucker and J. Balandeau. 1987. Stimulation of root exudation of rice seedlings by Azospirillum strains: carbon budget under gnotobiotic conditions. Biol. Fert. Soils 4:9-14.

Hussain, M., M.A. Malik, M. Farooq, M.Y. Ashraf and M.A. Cheema. 2008. Improving drought tolerance by exogenous application of glycinebetaine and salicylic acid in sunflower. J. Agron. Crop Sci. 194:193-199.

Jaleel, C.A., P. Manivannan, B. Sankar, A. Kishorekumar, R. Gopi, R. Somasundaram and R. Panneerselvam. 2007. Pseudomonas fluorescens enhances biomass yield and ajmalicine production in Catharanthus roseus under water deficit stress. Colloids Surfaces B. Biointerfaces 60:7-11.

Javaid, M.G., A. Sorooshzadeh, F. Moradi, S.A.M. Sanavy and I. Allahdadi. 2011. The role of phytohormones in alleviating salt stress in crop plants. Aust. J. Crop Sci. 5:726-734.

Ji, X., B. Dong, B. Shiran, M.J. Talbot, J.E. Edlington, T. Hughes, R.G. White, F. Gubler and R. Dolferus. 2011. 
Control of abscisic acid catabolism and abscisic acid homeostasis is important for reproductive stage stress tolerance in cereals. Plant Physiol. 156:647-662.

Nadeem, S.M., M. Ahmad, Z.A. Zahir, A. Javaid and M. Ashraf. 2014. The role of mycorrhizae and plant growth promoting rhizobacteria (PGPR) in improving crop productivity under stressful environments. Biotechnol. Adv. 32:429-448.

Niinemets, U. 2010. Responses of forest trees to single and multiple environmental stresses from seedlings to mature plants: past stress history stress interactions tolerance and acclimation. Forest Ecol. Manag. 260:1623-1639.

Price, A.H., J.E. Cairns, P. Horton, H.G. Jones and H. Griffiths. 2002. Linking drought resistance mechanisms to drought avoidance in upland rice using a QTL approach progress and new opportunities to integrate stomatal and mesophyll responses. J. Exp. Bot. 53:9891004.

Rai, V.K. 2002. Role of amino acid in plant responses to stresses. Biol. Plant. J. 45:481-487.

Rao, S.R., A. Qayyum, A. Razzaq, M. Ahmad, I. Mahmood and A. Sher. 2012. Role of foliar application of salicylic acid and L-tryptophan in drought tolerance of maize. J. Anim. Plant Sci. 22:768-772.

Ryan, J., G. Estefan and A. Rashid. 2001. Soil and Plant Analysis Laboratory Manual, $2^{\text {nd }}$ Ed. International Center for Agriculture in Dry Areas (ICARDA), Aleppo, Syria.

Saharan, B.S. and V. Nehra. 2011. Plant growth promoting rhizobacteria a critical review. Life Sci. Medic. Res. 21:1-30.

Saini, H.S. and M.E. Westgate. 2000. Reproductive development in grain crops during drought. Adv. Agron. 68:59-96.

Shaharoona, B., M. Naveed, M. Arshad and Z.A. Zahir. 2008. Fertilizer dependent efficiency of Pseudomonads for improving growth, yield, and nutrient use efficiency of wheat (Triticum aestivum L.). Appl. Microbiol. Biotechnol. 79:147-155.

Steel, R.G.D., J.H. Torrie and D.A. Dickey. 1997. Principles and procedures of statistics: A biometrical approach. $3^{\text {rd }}$ Ed. WCB/McGraw-Hill Co., Boston Mass, USA.

Subbarao, G.V., R.M. Wheeler, L.H. Levine and G.W. Stutte. 2001. Glycinebetaine accumulation, ionic and water relations of red-beet at contrasting levels of sodium supply. J. Plant Physiol. 158:767-776.

Suzuki, N., S. Bajad, J. Shuman, V. Shulaev and R. Mittler. 2008. The transcriptional co-activator mbf1c is a key regulator of thermo tolerance in Arabidopsis thaliana. J. Biol. Chem. 3:45-56.

Timmusk, S. and E. Nevo. 2011. Plant root associated biofilms. In: D.K. Maheshwari (ed.). Plant Nutrient Management. Springer Verlag, Berlin, Germany.

Timmusk, S. and E.G. Wagner. 1999. The plant-growthpromoting rhizobacterium Paenibacillus polymyxa induces changes in Arabidopsis thaliana gene expression a possible connection between biotic and abiotic stress responses. Mol. Plant Microbe Interactions 12:951-959.

Timmusk, S. and L. Behers. 2012. Rhizobacterial application for sustainable water management on the areas of limited water resources. Irrig. Drain. Syst. Engin. 12:2168-9768.

Timmusk, S., I.A.A. El-Daim, L. Copolovici, T. Triin, A. Kannaste, L. Behers, E. Nevo, G. Seisenbaeva, E. Stenstrom and U. Niinemets. 2014. Drought-tolerance of wheat improved by rhizosphere bacteria from harsh environments: enhanced biomass production and reduced emissions of stress volatiles. PLOS One 9:1-13.

Wang, C., A. Yang, H. Yin and J. Zhang. 2008. Influence of water stress on endogenous hormone contents and cell damage of maize seedlings. J. Int. Plant Biol. 50:427434.

Wang, W., B. Vinocur and A. Altman. 2003. Plant response to drought salinity and extreme temperatures towards genetic engineering for stress tolerance. Planta 218:1-14.

Wolf, B. 1982. A comprehensive system of leaf analysis and its use for diagnosing crop nutrient status. Comm. Soil Sci. Plant Anal. 18:131-147.

Yang, X. and C. Lu. 2005. Photosynthesis is improved by exogenous glycinebetaine in salt-stressed maize plants. Physiol. Plant. 124:343-352.

Yang, J., J. Zhang, Z. Wang, G. Xu and Q. Zhu. 2004. Activities of key enzymes in sucrose-to-starch conversion in wheat grains subjected to water deficit during grain filling. Plant Physiol. 135:1621-1629.

Zahir, A.Z., M.A.R. Malik and M. Arshad 1999. Effect of auxins on the growth and yield of rice. Pak. J. Agric. Sci. 36:3-4. 